\title{
The Impact of Ethics on Job criminalization
}

\section{El impacto de la ética en la criminalización laboral}

\author{
Narjes Arbabi
}

PhD Student, Department of Jurisprudence and Fundamentals of Islamic Law, Mashhad Branch, Islamic Azad University, Mashhad, Iran

https://orcid.org/0000-0002-5682-6915

\section{Mohammad Reza Kazemi Golvardi}

Assistant Prof., Department of Jurisprudence and Fundamentals of Islamic Law, Mashhad Branch, Islamic Azad University, Mashhad, Iran

https://orcid.org/0000-0003-3343-7164

\section{Abbas Sheikholeslami}

Assistant Prof., Department of Criminal Law and Criminology, Mashhad Branch, Islamic Azad University, Mashhad, Iran

https://orcid.org/0000-0003-3975-6844

*Correspondence

Email:Mr_kazemigolvardi@yahoo.com
Cite as:

Arbabi, N., Kazemi Golvardi, MR., \& Sheikholeslami, A. (2021). The Impact of Ethics on Job criminalization. Propósitos y Representaciones, 9 (SPE3), e1154. Doi: http://dx.doi.org/10.20511/pyr2021.v9nSPE3.1154 


\section{Summary}

The criminalization of some jobs can be traced in the law system of all countries. The criteria for this criminalization vary according to the legal system of each country. In Iran, job criminalization is based on the approach of Imami jurisprudence, which is a text-oriented and sometimes intellectoriented paradigm. Therefore, jurisprudence determines whether a job is criminal or not. Along with theology and ethics, the science of jurisprudence constitutes the three scientific pillars of Islam. The relationship between these three is one of the fundamental discussions that have great impacts on the attitude of scholars of jurisprudence in dealing with issues. Among these, the relationship between ethics and jurisprudence is very important because these two are formed on the basis of instructions and warnings and it has caused a disagreement among Islamic scholars about their relationship. Some deny their relationship, some believe that ethics requires jurisprudence, and some consider jurisprudence to require ethical supervision. These variations have led to differences in their perceptions of issues. Of course, looking at the meaning of ethics and jurisprudence, it is clear that the two are in close contact with each other, and since human behavior must be accepted by God in order to lead to human happiness, ethics acts as an observer of jurisprudence. This effect is sometimes based on the imaginary and affirmative principles of jurisprudence, and sometimes on the methods of jurisprudence. These effects can be observed in the difference between a job criminalization, which is mentioned in this article.

Keywords: impact of ethics, criminalization, jobs, presumptions, imaginary principles, affirmative principles, methods.

\section{Resumen}

La criminalización de algunos trabajos se puede rastrear en el sistema legal de todos los países. Los criterios para esta criminalización varían según el sistema legal de cada país. En Irán, la criminalización del trabajo se basa en el enfoque de la jurisprudencia Imami, que es un paradigma orientado al texto y, a veces, al intelecto. Por tanto, la jurisprudencia determina si un trabajo es criminal o no. Junto con la teología y la ética, la ciencia de la jurisprudencia constituye los tres pilares científicos del Islam. La relación entre estos tres es una de las discusiones fundamentales que tienen un gran impacto en la actitud de los estudiosos de la jurisprudencia al abordar los temas. Entre estos, la relación entre ética y jurisprudencia es muy importante porque estos dos se forman sobre la base de instrucciones y advertencias y ha causado un desacuerdo entre los eruditos islámicos sobre su relación. Algunos niegan su relación, algunos creen que la ética requiere jurisprudencia y algunos consideran que la jurisprudencia requiere supervisión ética. Estas variaciones han dado lugar a diferencias en sus percepciones de los problemas. Por supuesto, al observar el significado de la ética y la jurisprudencia, queda claro que las dos están en estrecho contacto entre sí, y dado que el comportamiento humano debe ser aceptado por Dios para conducir a la felicidad humana, la ética actúa como observadora de la jurisprudencia. . Este efecto a veces se basa en los principios imaginarios y afirmativos de la jurisprudencia y, a veces, en los métodos de la jurisprudencia. Estos efectos se pueden observar en la diferencia entre una criminalización laboral, que se menciona en este artículo.

Palabras clave: impacto de la ética, criminalización, trabajos, presunciones, principios imaginarios, principios afirmativos, métodos.

\section{Introduction}

Among the Abrahamic religions, Christianity has relied only on moral beliefs and has abolished legitimacy through the New Testament (Hashemi, 2010). And on the other hand, the Orthodox Judaism, with all its intensity, has clung only to the Sharia and looks at religion through the lens of the Sharia (Alikhani, 2019: 77). Meanwhile, Islam is mentioned as a moderate religion in the Quran (Baqarah 2: 143). This is because the religion of Islam consists of three parts: beliefs, 
ethics, and jurisprudence (Motahari, 2014), and these three are closely linked to each other in such a way that the rules of these three are stated in the Quran not separately but in an intertwined way (Ghasemi, 2015).

However, in the meantime, some believe that the jurists of these three sciences are considered as apart from each other. Therefore, in various jurisprudential positions, they have not paid attention to the ethical rules for inferring the decrees and have practically abandoned them (Ali Akbaryan, 2015: 17), and willingly or unwillingly, this method in inferring the decrees has also spread to the legislators because the Iranian law is influenced by Shiite jurisprudence (Mousavi Bojnourd, Seyed Mohammad 2016: 32). While some jurists believe that there is a close relationship between jurisprudence and ethics and ethics has influenced jurisprudence (Mousavi Bojnourd, Seyed Mahmoud 2016: 90), The same difference in the viewpoint and inference of the decrees causes a difference in the expression of criminalization of some jobs based on the principles of jurists (Zohravi, 2016: 36-42). And, perhaps based on the views of jurists who believe that ethics has no effect on jurisprudence, the criminalization of some jobs is simply acceptable or unacceptable. While among the jurists who believe in the connection between ethics and jurisprudence in inferring rulings, the criminalization of some jobs or non-criminalization of others is not easily acceptable. So the question is how effective the ethics might be on criminalization of jobs? There has been no Persian research on this subject so far. Only have a few studies examined the relationship between ethics and jurisprudence, and some others have dealt with the effect of ethics on criminalization in jurisprudence, but none of them has examined the effect of ethics on criminalization of jobs in a case study.

\section{Views on the Relationship between Ethics and Jurisprudence}

There is disagreement among Islamic scholars about the relationship between jurisprudence and ethics. Some jurists of these two sciences are considered to be separate. Therefore, in many jurisprudential positions, no attention has been paid to the moral rules in inferring the rulings and it has practically been abandoned (Ali Akbaryan, 2015: 17). This view seems to be contradictory, that is, it does not establish any relationship between jurisprudence and ethics. This view can be observed in some jurists' work, although they may not be theoretically obligated to it, but in practice this view can be followed in their jurisprudential inferences. For example, in discussing the duties of a wife with a purely jurisprudential view, the wife will have no affirmative duty other than special obedience. And other duties are privative, such as not cheating, not going out without permission, and unjustifiable disobedience. While in an ethics-oriented view, the duty of raising children, managing household chores, etc. is the responsibility of the wife without any financial expectations (Jowkar, 2011). In this group, there are thinkers who consider the difference between jurisprudence and ethics in that the legal issues are related to material problems while ethics is concerned with spirituality (Katouzyan, 1973, 1: 404). This view also refers only to the part of jurisprudence and law that explains the relations between individuals, and in this regard, only the material aspect is considered. In this case, there is a contradiction between ethics and the law of the relationship, while some of the legal provisions are derived from ethics, such as the order to have good relations between couples (Article 1103 of the Civil Code).

Another view holds that there is a relationship between jurisprudence and ethics, but there are huge differences. Some of them believe that because the goal of jurisprudence is to regulate the external relations of human and recognize ethics as something to regulate the internal relations of human, ethics needs jurisprudence, and the opposite is not true (Fakhar Tousi, 2013: 35).

However, another group considers the end of jurisprudence as raising the individual and his spirituality, organizing the society and the hereafter reward and penalty, while the goal of ethics is to correct the disadvantages of the individual and society and the difference between the two is considered to be in not paying attention to the hereafter reward and penalty and therefore, a connection and relation is known to be established between the two (Mousavi Bojnourd, Seyed Mahmoud, 2016: 89). In other words, in the external realization, ethical jurisprudential schools have influenced jurisprudence. For example, due to the sharing of resources, the two have been effective on each other (Mousavi Bojnourd, Seyed Mohammad, 2016: 35).

Some also consider the difference between ethics and jurisprudence to be that in ethics the 
intention of individuals enjoys a concrete prestige, and it is the condition of the value of an action. However, in the legal- jurisprudential discussions, the only criterion is action, no matter what the intention is; and this means that jurisprudence has a pragmatic view of actions (Mahdavi Kani, 2016: 395). In this view, the difference between the two sciences is expressed based on the nature of the formation of its decrees. Therefore, it can be said that the relationship between these two includes the general and specific manners simultaneously. It means where jurisprudence emphasizes intentions, it interferes with ethics, such as the discussion of worship, and where external actions are central to jurisprudential debates, it does not deal with ethical issues as the social law does. However, this can also be questioned because the principle of "existing a malintent" in the legal criminalization of crime (Ardebili, 2007: 121) is derived from ethics and this principle is not consistent with the difference between law and ethics, because it is said that the intention is not paid any attention to in law, while ethics makes it a criterion for action.

Regarding the relationship between ethics and jurisprudence, Allameh Tabatabayee believes that the principles of Islamic jurisprudence and law are based on ethics (Tabatabayee, 2016: 32). In this case, ethical issues are considered as imaginary and affirmative principles of jurisprudence, which, along with other issues such as theological and philosophical issues, are placed in the minority or majority of jurisprudential analogies. Therefore, the relationship between jurisprudence and ethics is a longitudinal relationship in which recognition of some jurisprudential issues depends on the recognition of ethical issues. In this case, jurisprudence requires the principles of ethics.

Regarding what was mentioned, it can be concluded that there are two dominant views among Islamic thinkers. One is the distinctive view that does not accept any relationship between jurisprudence and ethics. Another is the relational view that establishes a relationship between ethics and jurisprudence. However, there are different perspectives among these views, from the spectrum that considers ethics to require jurisprudence to the spectrum that considers jurisprudence to require ethics.

\section{The meaning of jurisprudence}

It seems that what is needed to know the reality of this issue is to first understand the meaning of jurisprudence and ethics, because in the meaning of jurisprudence and ethics, each of the thinkers has taken a separate path, and this has led to such distinct results from each other. Get. Therefore, it should be known that the meaning of jurisprudence has changed over time, which can be divided into four types of definition.

The first absolute meaning of understanding is that it is considered as the meaning of jurisprudence. The second meaning is the understanding of religious teachings, which is the general meaning of jurisprudence, and the third meaning is the understanding of the sub-rules of religious practice, which is interpreted as the specific meaning of jurisprudence. It has been interpreted as a special meaning of jurisprudence (Zahiri, 2012: 12). According to the definitions provided, what is meant by this article is the fourth meaning of the concept of jurisprudence, which is the sub-rules of religious practice that are obtained through ijtihad, but it should be known that in the historical course of jurisprudential books, it is possible. He observed that the early books of the jurists were full of moral precepts, and he considered these cases to be among the sub-practical rules of Sharia. While in the writings of contemporaries such as Tahrir and Mesbah al-Fiqah, there is no trace of moral issues (Rokni Dezfuli and Hedayati, 2016: 10).

According to this point, it should be known that jurisprudence in this sense includes instructions to explain the relationship between people and God. (Worship) is the relationship of individuals with other people (civil rights), the relationship of individuals with other beings (environmental rights) and the relationship of individuals with themselves. In this view of jurisprudence, any do's and don'ts should be included in jurisprudence, and jurisprudence is obliged to comment on it. In this case, the do's and don'ts, whether religious or instructive, are within the circle of jurisprudence.

\section{The meaning of morality}

But about the meaning of ethics, it should be said that in the terminological meaning of this word, various applications can be observed and each of the scientists of ethics has considered a special 
definition for ethics according to their theoretical foundations, the first meaning that can be written for ethics. Experts have observed that it has interpreted morality as "carnal state." In the definition of morality, Yahya Ibn Uday (272-365 AH) considers it as a state of the soul by which a person does his work without thought and authority (Ibn Uday, 2013: 13); And like this definition, Ibn Muskawiyyah (326-421 AH) has stated in the meaning of creation, he interprets morality as a state of mind that makes a person do something without thinking (Ibn alMuskawiyyah: 41). The difference between Ibn al-Muskawiyyah's definition and Ibn 'Uday's is that he introduces morality as a motivation for thought, while Ibn' Uday has interpreted it as a cause for behavior. In Ibn Muskawiyyah's definition, morality is the prelude to behavior, and in Ibn 'Uday's definition, morality is considered the cause of behavior. However, in both definitions, gender is considered to be a state of mind, which includes transient human behaviors.

The second definition of ethics is its definition of "sustainable psychic attributes" which, according to Allameh Mohammad Taghi Mesbah Yazdi, is the most common and common term for the use of the term ethics among Islamic thinkers and scientists, and is: In proportion to them, they become spontaneous and without the need to think and reflect on human beings "(Mesbah Yazdi, 2012: 20). In this definition, the reason for the issuance of mood verbs is also known as the morality of traits that include spiritual properties, as a result of which mental states such as instant anger, as well as traits that are issued from thought and thought, such as Stingy forgiveness goes beyond the definition of morality. Confirmation of this interpretation is the definition given by Khajeh Nasir (597-672 AH) of morality, in which he interpreted morality as the queen of the soul: It is said that one of the sensual qualities of the one who was quick to say the present and the one who was gradual was called the queen (Khawaja Nasir al-Din al-Tusi, 2010: 101), with the difference that he does not consider Khawaja Khalq as the reason for issuing actions, but as appropriate or the cause. Incomplete issuance states. This meaning of ethics has an ancient history and has been accepted even by some ancient Greek thinkers such as Aristotle (384 BC-322 BC), and even today Western Aristotelian philosophers such as Pinkafs interpret this meaning of ethics. They confirm (Pinkafs, 2009: 405).

The third definition of ethics is its definition of "behavioral pattern." In this view of ethics, it has been interpreted as a pattern of internal and external communication behavior, based on respect for the rights of the other party (Qaramaleki, 2013: 122), which as a result of ethics is human behavior that is bound to stability and from That behavioral pattern can be extracted. This definition defines morality only in relation to the non-definite and has no view of the individual. As a result, it is an intrinsic matter that can be legally assessed because the criterion is the rights of the parties.

According to the definitions of morality, there are three views on morality in Islam, a view that considers morality to be a state of the human soul that unwittingly beats it. It should be a state of mind, because the verb is without the need for thought or the queen of man, or unwittingly beheads her. The second definition of morality is the stable adjective of the soul, which is unwillingly derived from him, in which case morality includes only the properties of the soul, and finally the third definition of morality is the pattern of behavior with the other person based on his rights.

Looking at the above definitions, not all of these definitions are comprehensive in any way. Because if morality is considered a state of mind or a trait of stability, the science of ethics is obliged to examine the intrinsic effects of these states or attributes. As a result, scientific ethics is defined as being devoted only to one's relationship with oneself, leaving no need for a connection between ethics and jurisprudence, Because in this case, scientific ethics becomes internal and mental. As some have suggested (Fakhar al-Tusi, 2013: 35), while one point has been overlooked here that in this view the mood has been considered to be the cause of total or incomplete behavior, so its status becomes extrinsic. And it can be used as an imaginary or affirmative basis in deriving practical sentences. But the third definition, which defines ethics as a pattern of behavior based on the rights of the parties, has an intrinsic status and considers the cause of the behavior to be an external factor, and that is the existence of the right of the other party. In this view of ethics, the task of this knowledge is to examine behavioral patterns based on the rights of the parties, and as a result, morality itself will be measured by legal criteria, and morality will need a legal system based on which it will be measured. So morality needs jurisprudence. And this view has degraded morality to the extent of a part of jurisprudence, because this definition of morality is a scientific 
way of relating to legal propositions.

However, ethics and its instructions seem to go beyond the issues presented in these two definitions, because moral issues sometimes involve human relations with oneself and sometimes involve individual issues around other people and sometimes include Issues that are related to one's relationship with God and ultimately cover the issues of man's relationship with the environment (Haqqani Zanjani, 2009). In this case, it can be said that the science of ethics is the same as jurisprudence in terms of issues. In this case, the question that arises here is what is the difference between jurisprudence and ethics? It should be noted that in jurisprudence, it seems that the main concern is to achieve the apparent rules of behavior in order to achieve the components and the innocence of the obligor. While ethics not only considers this level but also considers beyond it, that is, the acceptability of one's actions and perfection (Ahmadpour, 1392: 146). Therefore, the conditions for accepting one's behavior and perfection in morality are stated. Given this importance, the question must be asked whether in the Shari'a, only the permission of the Shari'a is considered, or whether their acceptance is also relevant to the Shari'a. In the first case, jurisprudence is separated from morality and there is no connection between the two, but jurisprudence is dedicated to the expression of the minimum of religion, and morality is responsible for the maximum growth of religion. In this case, a person can be saved without having morals. And in the second case, jurisprudence in order to reach human perfection requires the integration of another component, namely morality, in which case morality is a necessary condition for the fruitfulness of jurisprudence, and as a result, jurisprudential rulings need to be monitored from a moral point of view. They shake hands.

In answer to this question, it should be noted that what can be understood from Islamic law is that it is important that man does not achieve happiness with jurisprudence with us, that is, jurisprudence that is free from morality, because the end of jurisprudence is the innocence of all people, which The apology and abstinence of the verb is realized (Gharavi Esfahani, 2004, 3: 12) and this is not enough for human perfection alone (Javadi Amoli, 2018: 51) and without perfection, human happiness, which is the main goal of God, will not be achieved (Haji Sadeghi, 2004). Therefore, it can be stated that behavioral acceptance, which is the prelude to human perfection and ultimately human happiness, is relevant to God, and this is achieved through morality, because morality is perfectionist in Islam (Abedi, Tabrizizadeh, 2014: 641). Therefore, jurisprudential propositions must pass through the filter of ethics, or consider ethics and jurisprudence as a single set of relations.

\section{The effect of moral propositions on jurisprudence}

Since all religious researches, whether moral or jurisprudential, are considered as interpretive propositions (Shabestari, 2010: 337). It remains to be seen how ethics affects the interpretive apparatus. There are several ways to understand a work. In classical hermeneutics, a final meaning of the work is considered. (P. 127) and in this case the presuppositions should not affect the commentator's point of view (Javadi Amoli, 2015: 279), but philosophical hermeneutics does not recognize something called "ultimate understanding" and phenomena called "author's intention", and Understanding is something that arises in the mind of the interpreter, and the understanding of any interpreter depends on various factors such as time, culture, education, etc., and these assumptions subconsciously influence the interpreter's understanding. (Vaezi, 2007: 127). The third view is the view between the two views. This view does not accept the view of philosophers like Martin Heidegger as a whole, because although there is pluralism in understanding, and this is an obvious statement, it cannot be stated with certainty that each One can violate the credit rules of the word and claim any irregular understanding. Rather, in understanding the text, in addition to believing in the existence of the ultimate concept, it should be noted that the audience's assumptions affect the understanding of the text (ibid: 449). According to these three approaches, what seems to be correct is the third view, so the legislator's own mental presuppositions are one of the effective pillars in deriving laws (Nasri, 2012: 123). Therefore, if the legislator has moral presuppositions, these presuppositions are effective in his inference of rulings (Raminpour, Azarnia, 2018: 38). These presuppositions affect the principle and the whole of jurisprudence, the principles of jurisprudence, the methods of jurisprudence, jurisprudential issues, and the structure 
of jurisprudence. The presuppositions that affect the whole of jurisprudence, since it is prior to jurisprudence, are in the field of theology and philosophy and have an effect on the proof and negation of jurisprudence itself. The presuppositions affecting the issues of jurisprudence also determine the limits and duties of the science of jurisprudence, which is a fundamental discussion and one of the issues of additional philosophy. As this section is strongly related to the discussion of the structure of jurisprudence, because here too it must be determined what are the goals and tasks of the science of jurisprudence? After that, discuss the structure and clarify what chapters of jurisprudence are included. Therefore, the topics of these two are all topics of philosophy of jurisprudence (Malekian, 2011: 14; Mehrizi, 2006: 20). As a result, both types of assumptions affecting the structure and issues of jurisprudence are out of the question.

Therefore, the effective presuppositions on the method of jurisprudence that discuss the methods of deriving rulings, and the effective presuppositions based on the internal principles in the discussion. The very assumptions that affect the principles are sometimes among the categories of perceptions that affect the subject or predicate of propositions (Ibn Sina, 2011: 3-4) and sometimes they are considered as acknowledgments that are effective in Soghari and Kobra Barahin (Mulla Sadra, 2013: 99), either explicitly or implicitly in propositional analogies. That is, they act in a small and cobra way or a deleted result (Muzaffar, 2011: 295), or in the form of a comparison in the comparative analogies of Mofasal (Ibn Sina, 2015: 92). These moral propositions themselves are available in the form of narrations and verses and in the form of supplies and results of verses and hadiths in the form of ijtihad propositions.

\section{The impact of ethics on imagery}

One of the occupations that can be considered a crime under Article 639 (b) of the Islamic Penal Code is the making of advertisements using women's foreheads. Here, the meaning of feminine is the beautiful face of women, whose covering is not obligatory among Imami jurists (Mohaghegh Isfahani, 2005, 1: 189), but if this action is done knowingly, some people look at this woman. Corruption occurs. According to some jurists, a woman's face should be covered. And from the jurisprudential basis of this article, we can refer to the rule of the sanctity of donations on penance (Tabatabai Yazdi, 2010, 2: 320), based on this rule from the point of view of Sheikh Ansari, any act that is considered as a prelude to another action and intends to do so. The act of forbidding haram is called aant (Sheikh Ansari, 1:32) and from the application of the words of the jurists it is inferred that aant is either of two types of intellectual and spiritual or practical and material assistance; Therefore, behaviors such as incitement, persuasion, etc. are also considered donations (Mohaghegh Damad, 2006, 4: 179).

However, some jurists have considered this issue, ie showing the face, if it causes a sinful look, as one of the examples of donations to the sinner (Shahidi, 2018), While others have considered it as an example of this rule (Tabatabai Yazdi, 2010, 2: 320; Modarressi, 2006, 1: 298). Here the difference between the two perspectives stems from the two types of imagery of a subject. Those jurists who do not consider the opening of the face in this case as an example of cooperation on sin, believe that such an act is not a donation, and this act is like selling a knife with which one can commit a crime. In other words, it is subject-making, that is, it creates the subject of sin. And Malekf is not responsible for creating the subject of sin (Shahidi, 2018). While jurists who believe that this is a cooperative on sin are responsible for even creating a forbidden subject, this difference is based on the idea of a subject based on moral principles. Because in this view, the individual is not only responsible for his own happiness and cruelty (sanction "6" 66), but also for the happiness and cruelty of others, and his happiness depends on preventing others from denying (Sheikh Mofid, 2013: 808). This notion makes even the subject of sin a donation. While other jurists consider this issue as a moral matter and do not consider it in the field of jurisprudence.

\section{The impact of ethics on affirmative action}

Regarding the way of recognizing the good and the bad of actions in Islam, some people consider only the religious statement as a proof. (Afshar, 2012: 9) and some in addition to the religious way also confirm the rational way (Meshkini, 2002: 184). But regarding the intrinsic goodness and ugliness that is discussed in the position of proof, in practice, everyone disagrees that the goodness and ugliness of actions are determined by God, and in fact in the wind of proof, the theory of divine command about the goodness of actions is determined, have accepted (Afshar, 
2012: 9). However, some Imams have considered the theory of the divine command to be specific to Ash'arites (Mesbah, 2012: 88) and have confused the two positions of ontology and epistemology. However, as a proof, the jurists have not followed a single method and have sometimes ruled on the inherent goodness and ugliness of actions, sometimes on their proper goodness and ugliness, and sometimes on the transverse goodness and ugliness. For example, in the discussion of his Muharram teachings, some consider jobs to be inherently forbidden, and some for results and some for intentions (Mohaghegh Helli, 2008, 2: 4). This shows that they did not use the same method in dealing with the study of verbs, although they claimed that good is the ugliness of intrinsic verbs (Allameh Helli, 1982: 82). This means that the norm that is the criterion for determining the good and bad of actions is one of the issues of moral philosophy; The results of which are evident in jurisprudence.

Ethical schools according to the criterion of goodness and ugliness of actions or in the exact interpretation of their normative study (Mesbah Yazdi, 2005: 24) to several groups, virtuous, conscientious and result-oriented, contract-oriented (Pinkafs, 2013: 16), Intentional, can be divided. Virtualists believe that the good and the bad of actions are due to the subject of the verb. (Frankena, 2017: 140-142) In the sense that if the perfect human agent is in terms of knowledge, courage, moderation and fairness, his actions are moral. (Dabiri, 2015: 8).

Conscientious ones, on the other hand, view behavior as good, which is the duty of the individual or group in each situation (Darwell, 2013: 95). In fact, they are action-oriented who consider inherent goodness and ugliness for actions and consider the current goodness as a criterion (Sadeghi, 2011:95) and the resultantists consider good behavior as having good results (Mazaheri Seif, 2018) and moral belief is justified only if certain people agree on it in certain circumstances and circumstances, or on the rule or system that it contains (Sharifi, 2014). In their interpretation, intentionalists also consider only the good things that a person has done with good intentions and consider the verb itself as good in relation to goodness and ugliness. , 1377: 35).

The difference between these views is that the conscientiousness of the truth is due to the necessity that lies in the verb itself, and therefore the correctness or incorrectness of the verb lies in its nature (Movahedi, 2010: 166). Therefore, this view recognizes the inherent goodness and ugliness and considers any external action to be inherently good or ugly. However, he considers the conclusion of actions to have no inherent goodness and ugliness, and considers goodness to be ugly depending on the result of the verb. In this view, the results of verbs can be divided into two types of goodness and ugliness, and based on those actions, they are also described as temporary goodness and ugliness. As a result, the effects and results of innate goodness and ugliness are found to be objective and external. Thus, according to this view, at least some beings are inherently good or good or ugly (Darwell, 2013: 1). Therefore, if the result of the creature is ugly, the causal verb is also ugly, and if the result of the creature is good, the causal verb is also considered ugly.

Virtues believe that the action of the moral agent is good, and the criterion of goodness and ugliness is the action of his own existence. In this case, neither of the two currents can be inherently characterized by good ugliness. As a result, in this moral view, intrinsic goodness and ugliness are also meaningless. And even the effects cannot be described as good and ugly, because every action of the moral agent both acts itself and the result is good, and in this case we see relativism in actions (Enayati, 2008: 35).

In the view of intentionalists such as Kant, the goodness and ugliness of the verb can be considered conditional on the intention of the subject, that is, the verb itself is inherently unconditional, and it is the intention that determines its goodness or ugliness, and actions are inherently lacking goodness and ugliness (Mesbah, 2012: 81).

Belief in each of these moral schools is influential in the discussion of actions, in the inference of rulings by the jurist. For example, based on conscientiousness in the discussion of occupations, since the verb itself has inherent goodness and ugliness, they can be considered inherently forbidden, and therefore occupations that some jurists consider inherently forbidden (Mohaghegh Helli, 2008, 2: 4). Like sculpture, Ghana is acceptable.

But in the conclusion of the job itself, the job cannot be described as sacred, but because of the prosody, it is the result of good or bad that it is characterized by respect and dignity. Therefore, in this view, jobs cannot be considered inherently respectable. Rather, after the prosody, there are 
complications such as loss or benefit that the job is evaluated. Although this view results in relativism, its relativism is in the form of proof, not as proof, because it can be used to characterize verbs as a necessary sanctity. And as a proof, by examining the results of actions, one can conclude that some behaviors usually produce good results, as a result of which these actions have the proper goodness, and some behaviors usually produce ugly results. . Therefore, verbs can be divided into two categories, and occupations such as Ghana are also of this type, that is, they have the appropriate sanctity.

But relativism is more intense in virtue, because both as a proof and as a proof there is no criterion for distinguishing between jobs, because a job as a proof can both be characterized by good and can be characterized by ugliness. Because it is the source of issuance that can cause the good and ugliness of actions, and because this is the source of human issuance, an act of man without ugly virtue is the same and the same act of virtuous man is good. There is no need for goodness and ugliness, and all things are equal to good and evil, until the doer issues it. In this case, dividing jobs into ugly and good does not make sense, and such a division is not at all appropriate in this view.

However, intentionalists, in the position of proving the intention, consider actions without inherent goodness and ugliness, but in the position of proof, according to their intention, they divide them into good and ugly. This view, like virtue, will give way to relativism. Because in the position of proof, actions cannot be described as necessary goodness and ugliness, and every action varies according to the intention of the individual, and relativism in this view is much more severe than virtue and in this view the severity of this issue is twofold. That's a lot, because a verb from a single person can be both good and bad at the same time. In this case, as in the previous division, the division of jobs is meaningless.

\section{The Impact of Ethics on Methodology}

As it was said, the mental presumptions of a jurist may affect his jurisprudential method. To illustrate this point, one example is mentioned. According to Article 712 of the Islamic Penal Code adopted in 2013, if someone puts begging or cheating as his/her occupation and earns money through it, s/he will be sentenced to one to three months in prison. According to this law, three conditions must be met in the realization of the crime of begging: having physical strength, intention and habit to do so, and making a living by it. In short, jurists have offered three views on begging, a group that has officially banned it (Horr Ameli, 2009, 9: 436; Modarresi, 2003, 8: 224), and the second group which considers it as disgusting (Imam Khomeini, 2011, 2: 92), and another group that considers it impunible (Najafi, 2003, 41: 82). It seems that the jurisprudential basis of the criminalization of begging should have been based on the view of the first group, and in this case, crime is defined as a sin. Some of them (Behbahani, 4:216) use some verses to honor this practice, which considers honor for the believers (Monafeghoun (hypocrites) "63" 8) and as a result, they consider begging to be against honor. Also, the narrations mentioned in this regard testify that the believers should not despise themselves (Kelini, 2007, 5: 64) and consider begging as an example of humiliation of the soul. Another group (Makarem Shirazi, 2011, 3: 566) considers it as reasonably obscene ${ }^{1}$ and forbidden by Sharia, and the reason for this claim has been stated to be the narrations (Horr Ameli, 2009, 9: 436).

However, most of the recent jurists did not consider begging to be religiously prohibited (Tabatabayee Yazdi, 1420 AH, 2: 193; Kashef al-Ghatta, 2012: 36; Najafi, 2003, 41: 82; Imam Khomeini, 2011, 2: 92; Golpaiegani, 2003, 3: 1021). In order not to respect the sanctity of begging, they have stated the lack of proof of sanctity as the reason and lacking a reason for sanctity, they have established the principle of permissibility (Kashef al-Ghatta, 2012: 36). And finally, the narrations that forbid begging consider it as loathsome (Imam Khomeini, 2011, 2: 92; Javaheri, 2012, 8: 358). Also, according to the narrations that consider the testimony of the beggar to be unacceptable, some have considered the reason of that unacceptability to be the accusation of the beggar in accepting the property and testimony (Tousi, 2007 AH, 6: 244). They consider

\footnotetext{
1. It means the decree of independents is reasonable; i.e. begging is an example of abjection. Abjection is reasonably obscene. So begging is reasonably obscene.
} 
begging not to be religiously prohibited, because if begging was religiously considered prohibited, one's testimony was void due to immorality but not because of being accused (Golpaiegani, 2003, 3: 1021). This group of jurists considers the sanctity of begging to be graded which has been stated for some divine saints (Najafi, 2003, 41: 82). In fact, not begging is considered an ethical virtue that belongs to a particular group and does not include most people. And this is due to the presumption that the narrations forbidding begging are related to ethics, therefore they cannot be used in inferring the jurisprudential decrees. This confirms that the view of the separation between ethics and jurisprudence causes the jurists to take ethical narrations out of the circle of evidence in inferring the methodology of religious decrees. While the other group of jurists, who did not consider these narrations as ethical virtues, considers begging as inappropriate for all, therefore it can be regarded as a crime from the legal point of view.

\section{Conclusion}

Based on what was said, it is clear that there are several views among Islamic scholars on the relationship between ethics and jurisprudence, which generally includes two views: the view of general contradiction that considers jurisprudence as completely separate from ethics; and the second view which believes in the relationship between jurisprudence and ethics, with a difference that some of the scholars consider ethics to require jurisprudence. Some consider them to be common in resources and therefore consider them to be mutually effective on each other. Some consider their relationship to be of the general and specific manners simultaneously, that is, in cases where intention is effective on practice, a relationship can be established between the two, and in legal matters this relationship is denied. Finally, some consider the principles of jurisprudence to be a derivation of ethics. In order to clarify the existence or lack of this relationship, and if there is such a type, it is necessary to examine the meaning of jurisprudence and ethics in order to determine the relationship between the two. The study revealed that the jurisprudence considered in the science of jurisprudence involves the religious practical sub-rules that are obtained through ijtihad. However, there are three theories in the meaning of ethics, among which the theory of ethics in the sense of behavioral model places ethics below jurisprudence, and ethics in the sense of angel of worldliness only pays attention to examining the relationship between the individual and his/her own. As a result, there is a contradictory relationship between jurisprudence and ethics, and ethics, in the sense of the sensual state, includes the same sense of angel, but provided that the meaning of ethics is defined as the knowledge to improve the relationship of the individual with God, with other human beings, with the environment, and with himself/herself. In terms of gamut with jurisprudence, it is considered as meaning. And the difference between jurisprudence and it is that jurisprudence is responsible for the acquittal, while ethics is also responsible for its acceptability and perfection. And since human acceptance and happiness in the epistemological system of Islam take precedence over the elimination of duty, ethics will act as a monitor to jurisprudence. With the clarification of this relationship, it is required to know that ethics, as mental presuppositions, would influence the principles and methods of jurisprudence, the effect of which can be seen in the discussion of criminalization and non-criminalization of some jobs and its divisions. For example, in the impact of ethics on imaginary principles, it should be stated that the jurisprudence that considers subjectmaking for sin as an example of cooperation on sin, forbids advertising using the female face. However, those who do not have such a view do not consider this job to be religiously prohibited, and this is because some jurists consider the happiness of others as the duty of the individual, while others consider it in the field of ethics and do not accept its involvement in jurisprudence. Regarding affirmative presuppositions, it can be pointed out, for example, that affirmation of virtuous, or result-oriented, or intentional, or conscientious normativeness in rejecting or accepting inherent goodness and indecency, and consequently acceptance or non-acceptance of the existence of religiously prohibited jobs can be inherently effective.

Finally, in order to explain how ethics can affect the method of jurists, the following discussion is pointed out that states, from a jurisprudential point of view, begging is not a crime; but from an ethical point of view, in order to maintain human dignity, it is a forbidden and criminal act and this difference derives from the method of inferring sentences. If the ethical propositions in the 
inference are confirmed, the result is criminalization and if they are not included in the inference, begging is not considered a crime.

According to the above examples, it can be inferred that ethical propositions in criminalization of jobs had such a significant effect on three dimensions of imaginary and affirmative principles as well as the method of inferring the decree, such that some jobs are religiously forbidden based on the ethical propositions while lack of these propositions may cause the job to be religiously legitimate.

\section{References}

Abedi, Ahmad \& Isfahani, Razieh Tabrizizadeh. (2014). Comparative evaluation of Aristotelian theory of moderation and Islamic moral theory, philosophy of religion, number: 4.

Afshar, Zohreh. (2012). Good and Evil: Sharia or Rational, Quarterly Journal of Islamic Jurisprudence and Law Research, No. 28.

Ahmadpour, Mehdi. (2013). Islamic jurisprudence and ethics, comparative science, Qom: Islamic Culture and Science Research Institute.

AliKhani, Ismail. (2019). Ethics in Judaism, Moral Knowledge, No. 3.

Allameh Helli. (1982). Nahj al-Haqq and Kashf al-Sadq, Beirut: Dar al-Kitab al-Lebanani.

Behbahani, Masabih Al-Zalam Fi Sharh Mafatih Al-Sharia, Najaf: Al-Majd Al-Majid Al-Wahid Al-Behbahani Foundation.

Dabiri, Ahmad. (2015). Virtue in ethics, moral knowledge, number: 1.

Darwell, Stephen. (2013). Consequentialism, First edition, London: Blackwell Publishing

Enayati, Mohammad Javad. (2008). Good and Evil from the Perspective of Revelation, Journal of Quranic Research, No. 13-14.

Fakhar Tusi. (2013). The Relationship between Jurisprudence and Ethics, Research Institute of Islamic Sciences and Culture.

Frankena; William. (2017). Philosophy of Ethics, translated by Hadi Sadeghi, Qom: Taha.

Gharavi Esfahani, Sheikh Mohammad Hussein (2004), The End of Durability in the Explanation of Sufficiency, Qom: Al-Bayt Foundation against the Revival of Heritage.

Ghasemi, Ali Mohammad. (2015). Thematic interpretations and methods of dividing the teachings of the Qur'an, Maaref Magazine, No.: 96.

Golpaiegani, Seyyed Mohammad Reza. (2003). The Book of Martyrdom, Seyyed Ali Hosseini Milani, Qom: Facts.

Haji Sadeghi. (2004). The Perfect Man in Motahhari Thought, Ghobsatov No. 30-31.

Haqqani Zanjani, Hossein. (2009). Principles \& Criteria of Moral Issues, Quarterly Journal of the School of Islam, No. 2.

Hashemi, Seyyed Ali. (2010). Shari'a in Christianity, Maaref Magazine, No. 11.

Horr Ameli, Abu Ja'far. (2009). Detail of the Shiite means for studying the issues of Sharia, Qom: Al-Baytah Institute.

Ibn al-Muskawiyyah, Abu Ali Muhammad ibn Muhammad ibn Ya'qub, Tahdhib al-Akhlaq wa Ta'atir al-Iraq, Cairo: Maktab al-Thaqaf al-Diniya.

Ibn Sina. (2011). Alaei Encyclopedia, Tehran: Ahmad Khorasani Press.

Ibn Sina. (2015). Al-Najat Man Al-Gharq Fi Bahr Al-Dhalat, Tehran: Tehran University Press and Publishing Institute.

Ibn Uday. (2013). Tahdhib al-Akhlaq, Egypt: Al-Ahliya.

Imam Khomeini. (2011). Tahrir al-Waseela, Qom: Ismailian Press.

Javadi Amoli, Abdullah. (2015). Human Expectation of Religion, Qom: Esraa Publishing.

Javadi Amoli, Abdullah. (2018). Principles of Ethics in the Quran, Tehran: Esraa Publications.

Javaheri, Sheikh Mohammad. (2012). Explanations in the explanation of Al-Urwa Al-Wathqi, Beirut: Dar Al-Arif for Publications.

Jowkar, Mahboubeh. (2011). Mutual rights and duties of moral, jurisprudential and legal husbands and wives, Tahoora Magazine, No.: 8.

Kashef al-Ghatta ', Sheikh Ja'far. (2012). Kashf al-Ghatta', Najaf: The school of Kashif al-Ghatta 'al-'Amah.

Kelini, Mohammad Ibn Ya'qub. (2007). Al-Kafi, Tehran: Dar Al-Kitab Al-Islamiya. 
Mahdavi Kani, Mohammad Reza. (2016). Starting points in practical ethics, Tehran: Islamic Culture Publishing Office.

Makarem Shirazi, Nasser. (2011). Anwar al-Fiqh in the rulings of the purity of purity, Qom: Dar al-Nasr al-Imam Ali ibn Abi Talib.

Malekian, Mostafa. (2011). Discussions of the Philosophy of Jurisprudence, Qom: Islamic Studies and Research Center.

Mazaheri Seif, Hamid Reza. (2018). Consequentialist Ethics, Pegah Hozeh, No. 245.

Mehrizi Mehdi. (2006). An Introduction to the Field of Jurisprudence, Criticism and Opinion, No.: 2.

Mesbah Yazdi, Mohammad Taghi. (2005). Critique and Study of Moral Schools, Qom: Imam Khomeini Educational and Research Institute Publications.

Mesbah Yazdi, Mohammad Taghi. (2012). Philosophy of Ethics, Qom: Imam Khomeini Educational and Research Institute Publications.

Mesbah, Mojtaba. (2012). Specialized Quarterly of Revelation Ethics, No.: 2.

Meshkini, Sheikh Ali. (2002). Terminology of Principles, Qom: Al-Hadi Publishing.

Modarressi, Sayyid Muhammad Taqi. (2006). Islamic Jurisprudence Comments on Al-Urwa AlWathqi and Mahdhab Al-Ahkam, Beirut: Dar Al-Qara.

Modarressi, Seyyed Mohammad Taghi. (2003). Islamic Legislative Manhaj and Purposes, Tehran: Al-Madrassi Publications.

Mohaghegh Ardabili, Majma 'al-Fada'a wa al-Burhan fi Sharh Irshad al-Azhan, Qom: Islamic Publishing House.

Mohaghegh Damad, Seyed Mostafa. (2006). Rules of Jurisprudence, Tehran: Islamic Sciences Publishing Center.

Mohaghegh Esfahani. (2005). Kashf al-Latham, Qom: Publications of the school of Ayatollah Marashi.

Mohaghegh Helli, Najmuddin. (2008). Sharia of Islam in matters of halal and haram, Qom: Ismailian Institute.

Mojtahed Shabestari, Mohammad. (2010). Hermeneutics, Books and Traditions, Tehran: New Design Publications.

Motahari, Morteza. (2014). Divine Justice, (Collection of Works, Vol. 1) Tehran: Sadra Publications.

Motahari, Morteza. (2014). Introduction to Islamic Sciences, Tehran: Sadra Publications.

Mousavi Bojnourdi, Seyed Mohammad. (2016). A Study of the Role of Ethics in Jurisprudence and Law with an Approach to Imam Khomeini's Theories, Matin Research Letter, No. 31-32.

Movahedi, Mohammad Javad. (2010). A Study of the Relationship between Conscientiousness and Concurrency, Philosophical Research, No. 216.

Mulla Sadra. (2013). The treatise on imagery and authenticity, Qom.

Muzaffar, Mohammad Reza. (2011). Al-Mantiq, Qom: Islamic Publishing House.

Najafi, Sheikh Mohammad Hassan. (2003). Jawahar al-Kalam fi Sharh Sharia al-Islam, Beirut: Dar Ihya Al-Tarath Al-Arabi.

Nasri, Abdullah. (2012). The Secret of the Text, Tehran: Aftab Tose'e Publications.

Pinkafs, Edmund. (2009). Virtues, Journal of Criticism and Opinion, No. 19-20.

Pinkafs, Edmund. (2013). From the central issue to virtue-seeking, translated by Seyed Hamid Reza Hassani \& Mehdi Alipour, Qom: Mushr Maaref Daftar Office.

Qaramaleki, Faramarz. (2013). Ahad, An Introduction to Professional Ethics, Tehran: Majnoon Publications.

Raminpour, Saeed \& Azarnia, Marzieh. (2018). The default role in jurisprudence and criminal law with an approach to Imam Khomeini's views, Matin Research Journal, No.: 80.

Rokni Dezfuli, Mohammad Reza \& Hedayati, Mohammad. (2016). The necessity of separating the applications of the word jurisprudence to explain the relationship between jurisprudence and ethics, jurisprudential research, Mashareh: 4.

Sadeghi, Hassan. (2011). Rational and Quranic Reasons on the Intrinsic and Rational Good and Ugliness of Actions, Journal of Theological Knowledge, No. 3.

Shahidi, Mohammad Taghi. (2018). Lectures outside of jurisprudence, Qom: School of 
Jurisprudence.

Sharifi, Ahmad Hossein. (2014). Moral Contractivism, Theory of Justifying Moral Proposals, Maaref Magazine No. 22.

Sheikh Ansari, Morteza, Qom: Heritage of Sheikh Al-Azam.

Sheikh Mofid, Mohammad Ibn Mohammad. (2013). Al-Muqna'a, Qom: Sheikh Mofid World Millennium Congress.

Tabatabai, Sayyid Muhammad Hussein. (2016). Cases of Complexity, Asr and Marriage against the Holy Qur'an, Cairo: Dar Al-Safwa.

Tabatabai, Seyyed Mohammad Kazem. (2010). Al-Urwa Al-Wathqi, Qom: Islamic Publishing Institute.

Tusi, Khajeh Nasir. (2010). Naseri Ethics, Tehran: Kharazmi Publications.

Vaezi, Ahmad. (2007). Introduction to Hermeneutics, Tehran: Institute of Islamic Culture and Thought.

Zahiri, Hossein. (2012). The Relationship between Jurisprudence and Ethics, Qom: Imam Khomeini Institute.

Zohravi, Reza. (2016). The place of ethics in criminology from the perspective of jurisprudence and subject law, Master's thesis, Islamic Azad University, Quds Branch, Faculty of Humanities.

Quran 